\title{
GENETIC AND PHENOTYPIC CHARACTERIZATION OF ISOLATES OF Pyricularia grisea FROM THE RICE CULTIVARS EPAGRI 108 AND 109 IN THE STATE OF TOCANTINS
}

\author{
ANNE S. PRABHU ${ }^{1}$, MARTA C. FILIPPI ${ }^{1}$, LEILA G. ARAUJO ${ }^{2} \&$ JOSIAS C. FARIA ${ }^{1}$ \\ 'Embrapa Arroz e Feijão, Cx. Postal 179, CEP 75375-000, Santo Antônio de Goiás, GO, fax: (62) 533-2100, \\ e-mail: prabhu@cnpaf.embrapa.br; ${ }^{2}$ Universidade Federal de Goiás (UFG), Cx. Postal 131, CEP 74001-970, \\ Goiânia, GO, e-mail: leilag@ cnpaf.embrapa.br
}

(Accepted for publication on 24/07/2002)

Corresponding author: Anne Sitarama Prabhu

PRABHU, A.S., FILIPPI, M.C., ARAUJO, L.G. \& FARIA, J.C. Genetic and phenotypic characterization of isolates of Pyricularia grisea from the rice cultivars Epagri 108 and 109 in the State of Tocantins. Fitopatologia Brasileira 27:566-573. 2002.

\begin{abstract}
An epidemic of rice (Oryza sativa) blast occurred on cultivars Epagri 108 and 109 in the municipalities of Lagoa da Confusão and Duerê in the State of Tocantins, during the rice-growing season 199899. DNA fingerprinting and virulence phenotype analysis were utilized to determine the diversity of Pyricularia grisea isolates collected from these cultivars in one epidemic year. Rep-PCR analysis of isolates was done by using two primer sequences from Pot2. Two distinct fingerprint groups or lineages were identified among 53 isolates collected from nine different commercial fields. The virulence pattern of isolates retrieved from these two cultivars was analyzed in artificial inoculation tests utilizing 32 genotypes in the greenhouse. A dendrogram constructed from virulence phenotype data showed a

single group considering $77 \%$ similarity level. The predominant pathotype IB- 45 was represented by 47 of the 53 isolates corresponding to $83 \%$. Four other pathotypes (IB-1, IB-9, IB-13 and IB-41) were identified at random among the isolates from these cultivars. There was no relation between rep-PCR grouping and pathotypes. The results showed that the isolates of $P$. grisea recovered from cultivars Epagri108 and 109 in farmers' fields had narrow phenotypic and genetic diversity. The blast outbreak on these two cultivars one year after their introduction could be attributed to the new pathotype IB-45 or its increase, which was hitherto existing in low frequency.

Additional key words: Magnaporthe grisea, molecular markers, Oryza sativa, rep-PCR analysis, rice blast.

\section{RESUMO \\ Caracterização genética e fenotípica de isolados de Pyricularia grisea coletados em lavouras das cultivares Epagri 108 e 109 no Estado do Tocantins}

Foi constatada a ocorrência de uma epidemia de brusone, na safra 1998/99 nas cultivares de arroz (Oryza sativa) irrigado Epagri 108 e 109, nos municípios de Lagoa da Confusão e Duerê, do Estado do Tocantins, na safra 1998-99. Foram utilizados "DNA fingerprinting" e análise fenotípica de virulência para determinar a diversidade entre isolados de Pyricularia grisea coletados nestas duas cultivares no ano de epidemia. A análise de DNA dos isolados foi realizada utilizando rep-PCR para amplificação das sequências entre os elementos repetitivos Pot2. Dois grupos distintos de bandas polimórficas ou linhagens foram identificados entre os 53 isolados coletados em nove diferentes lavouras comerciais. O padrão de virulência dos isolados foi estudado através de inoculações artificiais em 32 genótipos, em casa de vegetação. O

dendrograma construído com base nos dados de virulência fenotípica, permitiu distinguir apenas um grupo, considerando o nível de similaridade de $77 \%$. O patótipo predominante IB-45 foi representado por 47 dos 53 isolados correspondendo a $83 \%$. Foram identificados quatro patótipos (IB-1, IB-9, IB-13 e IB-41) entre isolados coletados nestas duas cultivares. Não houve relação entre agrupamento dos isolados por rep-PCR e patótipos. Os resultados ainda demonstraram que os isolados de $P$. grisea provenientes das cultivares Epagri 108 e 109 apresentaram estreita diversidade fenotípica e genética. A epidemia da brusone nestas duas cultivares, um ano após o lançamento, pode ser atribuída ao surgimento do novo patótipo IB-45 ou à sua preexistência em baixa frequiência e rápido aumento no campo.
\end{abstract}

\section{INTRODUCTION}

Rice blast caused by Pyricularia grisea (Cooke) Sacc. [= Magnaporthe grisea (T.T.Herbert) Yaegashi \& Udagawa] is the most destructive disease of irrigated rice (Oryza sativa
L.) in the State of Tocantins. Even though there are no exact estimates of yield losses, they are considered to be significant by the growers in the blast susceptible cultivar Metica 1. Two rice cultivars Epagri 108 (17719/5738/IR 21015-72-3-3-31) and Epagri 109 (CT7347/ IR 21015-72-3-3-3-1) were 
Genetic and phenotypic characterization of isolates of Pyricularia grisea from ...

introduced from the State of Santa Catarina because of their high yield potential, grain quality and blast resistance. These two cultivars occupied approximately 20.000 hectares in the municipalities of Lagoa de Confusão and Duerê. The occurrence of blast epidemic was recorded, in different farms, at the vegetative phase, during 1998/99 rice-growing season a total breakdown of vertical resistance of these two cultivars in a year after their introduction (Prabhu \& Filippi, 1999). The resistance breakdown of commercial rice cultivars was attributed to high pathogenic variability of $P$. grisea $(\mathrm{Ou}$, 1980).

Most of the earlier studies in Brazil were concentrated on determining race composition, frequency of occurrence and compatibility with known resistance genes (Amaral et al., 1979; Ribeiro \& Terres, 1987; Prabhu \& Filippi, 1989; Urashima \& Isogawa, 1990; Filippi et al., 1999). Pathogenic variation has been reported from single conidial isolates originating from a single lesion (Ou \& Ayad, 1968; Bedendo et al., 1979), while some other studies showed that the isolates are pathogenically stable (Giatgong \& Frederiksen, 1969; Bonman et al., 1987). The pathogenic diversity is generally very high in experimental fields and breeding sites commonly known as "hot spots" where conditions are highly favorable for the pathogen (Correa-Victoria \& Zeigler, 1993; Zeigler et al., 1995; Filippi et al., 1999). However, there is no information in Brazil on the virulence diversity of the pathogen under natural conditions in farmer's fields where there is very little or no allo-infection.

Strategies to incorporate the non-matching resistance genes to the existing pathogen population in the field require studies on virulence and molecular characterization. Characterization of pathogen populations of $P$. grisea is done both by conventional pathotyping based on the reaction on a set of differentials and molecular tools such as DNA-fingerprinting. The MGR586 element has been widely used as a probe for genetic analysis of the blast pathogen population. It has been shown that the isolates of $P$. grisea can be grouped into distinct lineages (Hamer, 1991; Levy et al., 1991; Levy et al., 1993; Zeigler et al., 1995; Filippi et al., 1999). Because of difficulties involved in RFLP analysis of large samples of P. grisea, George et al. (1998) developed a cost effective, simple, repetitive, element-based polymerase chain reaction (rep-PCR) fingerprinting method, specific for monitoring $P$. grisea populations. A close correspondence between the groupings of isolates based on Pot 2 rep-PCR and those obtained by MGR586 was demonstrated.

The present paper reports the results of investigation on pathotyping and genetic diversity in isolates of $P$. grisea, retrieved from the commercial rice cultivars Epagri 108 and 109 planted in extensive areas, in the State of Tocantins.

\section{MATERIALS AND METHODS}

\section{Isolates}

Isolates of $P$. grisea were collected from nine rice farms planted with cultivars Epagri 108 and 109 during the 199899 crop growing season in the municipality of Lagoa de Confusão, in Tocantins. Monoconidial isolates from the sporulating leaf lesions were obtained and maintained on sterilized filter paper discs.

\section{DNA extraction}

Isolates were grown on culture medium $(10 \mathrm{~g}$ of dextrose supplemented with $2 \mathrm{~g}$ of yeast extract per liter) in Erlenmeyer flasks for four days without agitation followed by ten days with constant agitation in the dark, at room temperature. One or two mycelial paper discs were transferred to Erlenmeyer flasks (cap. $250 \mathrm{ml}$ ) containing $150 \mathrm{ml}$ of culture medium.

DNA extraction was performed utilizing the modified method of Raeder \& Broda (1985). The harvested mycelia were freeze-dried, lyophilized and macerated in liquid nitrogen. About $300 \mathrm{mg}$ of powdered mycelia was suspended in $700 \mu \mathrm{l}$ of extraction buffer ( $50 \mathrm{mM}$ Tris- $\mathrm{HCl}, \mathrm{pH} 8.0 ; 50$ $\mathrm{mM}$ EDTA; $3 \%$ sodium dodecyl sulfate, $\mathrm{wt} / \mathrm{vol}$ and $1 \%$ of mercaptoethanol) at $65^{\circ} \mathrm{C}$ for at least $1 \mathrm{~h}$. The cellular proteins were precipitated with $30 \mu \mathrm{l}$ of potassium acetate $(3 \mathrm{M}$ and $\mathrm{pH}$ 5.2). DNA was precipitated in $200 \mu \mathrm{l}$ of cold isopropanol, washed with $70 \%$ ethanol, dried under vacuum and resuspended in TE buffer $(10 \mathrm{mM}$ Tris- $\mathrm{HCl}, \mathrm{pH} 8.0 ; 1.0 \mathrm{mM}$ EDTA), containing $10 \mathrm{mg} / \mathrm{ml}$ of RNase A and incubated at $37^{\circ} \mathrm{C}$ for $30 \mathrm{~min}$. The DNA concentration was estimated by fluorometer and adjusted to $10 \mathrm{ng} / \mu \mathrm{l}$.

\section{Primers}

The oligonucleotide sequences were based on the primer sequence of the repetitive element Pot 2 (EMBL accession Z33638), an inverted repeat transposon found in approximately 100 copies in $M$. grisea (Kachroo et al., 1994). The two primers ( Pot2-1 5' CGGAAGCCCTAAAGCTGTTT $3^{\prime}$ and Pot2-2 5'CCCTCATTCGTCACACGTTC 3') were designed from each end of Pot 2 in opposite orientation such that the 3'ends were directed outward from each element (George et al., 1998). The two primers, whose sequences are internal to the 43-bp inverted terminal repeats, amplify the flanking sequences on both sides of the repetitive element, generating fragments spanning the intervening sequences (George et al., 1998). The oligonucleotide sequences were synthesized by Federal University of Paraná, Brazil.

\section{DNA Amplification}

DNA amplification reactions were performed as described by Williams et al. (1990). Each $25 \mu \mathrm{l}$ reaction contained: $50 \mathrm{ng}$ of DNA, $2.5 \mu \mathrm{l}$ of $10 \mathrm{X}$ buffer reaction (200 $\mathrm{mM}$ Tris - $\mathrm{HCl}, \mathrm{pH} 8.4$ and $500 \mathrm{mM}$ of $\mathrm{KCl}$ ), $0.75 \mu \mathrm{l}$ of 50 $\mathrm{mM} \mathrm{MgCl}{ }_{2} ; 0.5 \mu \mathrm{l}$ of dNTP (10 mM of each dATP, dGTP, dCTP and dTTP); $0.5 \mu \mathrm{M}$ each of the two opposing primers; 1.5 units of Taq polymerase, overlaid with $50 \mu \mathrm{l}$ of mineral oil to prevent evaporation.

In a preliminary test conducted, to determine the conditions of DNA amplification, the method described by 
Williams et al. (1990) was found to be superior to the protocol adopted by George et al (1998). For this reason the following procedure was adopted. The enzymatic amplification was performed in a thermocycler (M.J. Research, Inc.), programmed for 40 cycles. Each cycle was composed of: $15 \mathrm{~s}$ at $94{ }^{\circ} \mathrm{C}$ (DNA denaturation); $30 \mathrm{~s}$ at $35^{\circ} \mathrm{C}$ (annealing of the primers to the DNA template) and $1 \mathrm{~min}$ at $72^{\circ} \mathrm{C}$ (extension of the primers). After 40 cycles an extra extension step was performed for $7 \mathrm{~min}$ at $72{ }^{\circ} \mathrm{C}$. Amplification products were separated by gel electrophoresis on $1.4 \%$ agarose gel in TBE buffer ( $90 \mathrm{mM}$ Tris-borate and $2 \mathrm{mM}$ EDTA) containing 10 $\mathrm{mg} / \mathrm{ml}$ of ethidium bromide. DNA bands were photographed under ultra violet light, utilizing the photo documentation system, Eagle Eye II (Stratagene).

\section{Data analysis}

The Pot 2 rep-PCR profiles were analyzed based on the presence (1) or absence (0) of bands of same length. The data were analyzed using the program NTSYS-pc version 2.0/1997. The genetic distances were calculated by the coefficient of similarity of Jaccard. The matrix of genetic distances was used for grouping the isolates based on the method of Unweighted Pair-Group Method with Arithmetic Averages (UPGMA).

\section{Virulence analysis}

The phenotypic virulence of 53 isolates retrieved from cultivars Epagri 108 and Epagri 109 were tested on 32 genotypes, including 19 commercial irrigated rice cultivars, five near isogenic lines of CO39 and standard international differentials. Sixteen genotypes per plastic tray $(30 \times 15 \times 10$ $\mathrm{cm}$ ) containing $3 \mathrm{~kg}$ of soil fertilized with NPK were planted. Ten to twelve seeds of each genotype were sown in $5 \mathrm{~cm}$ rows. Inoculations were made on 21-day-old plants with spore suspension $\left(3 \times 10^{5}\right.$ conidia/ml) in the greenhouse. Leaf blast reaction was assessed seven to nine days after inoculation. The isolates that induced typical sporulating lesions were considered virulent (4-9) and non-sporulating necrotic lesions (0-3) as avirulent according to Leung et al. (1988). The frequency of virulence was determined on the basis of total number of compatible reactions on 32 genotypes. In case of ambiguous or intermediate reaction, inoculation tests were repeated whenever necessary and the ones that gave consistent and uniform reaction were utilized for analysis. The pathotypes were determined based on the reaction type on eight international differentials.

The virulence pattern was analyzed based on the similarity of reaction type among isolates. A binary matrix indicating compatible reaction (1) and incompatible reaction (0) of each isolate was utilized for constructing a matrix of similarity between all pairs of isolates according to the coefficient of Jaccard. These data were used to calculate similarity coefficients and to construct dendrograms using the unweighted pair-group method with arithmetic averages (UPGMA) employing the SAHN program of the Numerical Taxonomy and Multivariate Analysis (NTSYS-pc version 2.0/ 1997).

\section{RESULTS AND DISCUSSION}

A distinct banding pattern was generated utilizing repPCR with two primer sequences from Pot2. The amplified bands ranged from $200 \mathrm{bp}$ to $1300 \mathrm{bp}$ in length (Figure 1). All isolates of $P$. grisea recovered from Epagri 108 and Epagri 109 showed three to nine polymorphic bands. Three of the 19 isolates, Nos. 5, 8, and 16 identified as pathotypes IB-13, IB-1 and IB-9, respectively, showed differences in DNA profiles compared to the 16 other isolates of the pathotype IB-45 (Figure 1).

Cluster analysis (UPGMA) of 53 isolates showed two distinct groups, one formed by the isolates Nos. 26 and 39, and the other by the rest of the isolates, considering similarity coefficient of approximately 38\% (Figure 2). Forty of the 47 isolates of pathotype IB- 45 recovered from cultivars Epagri

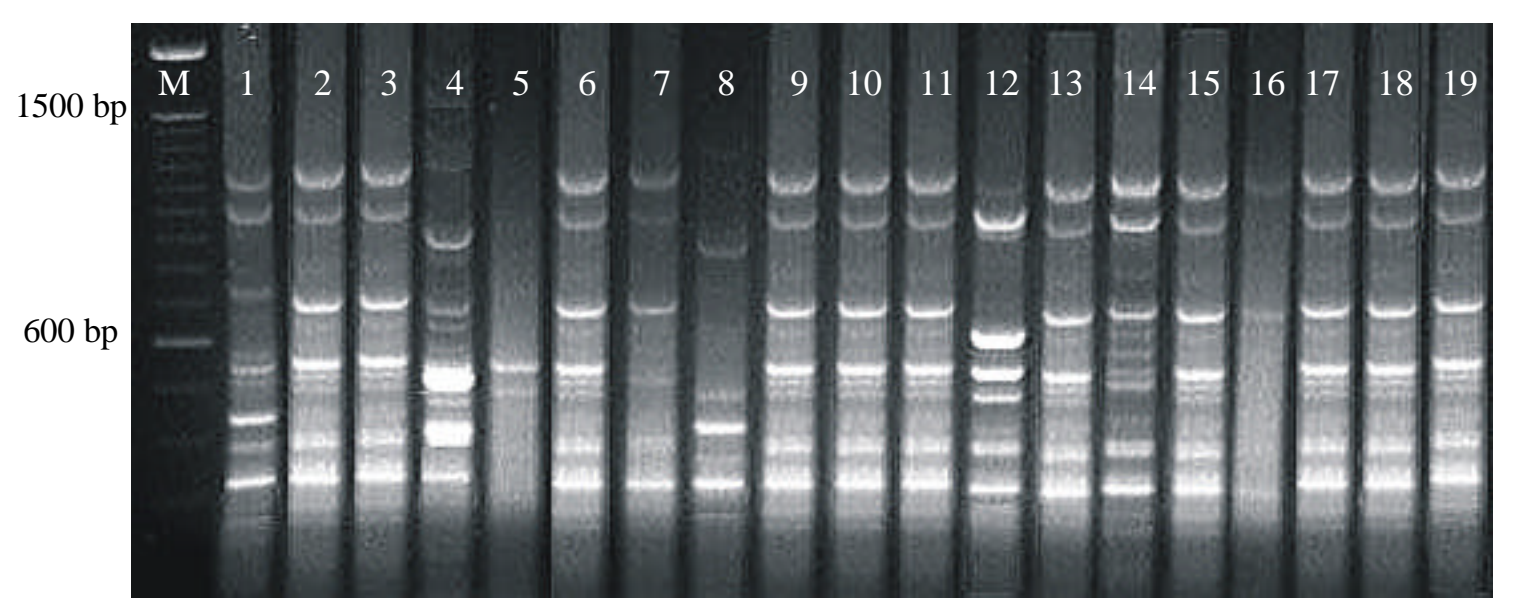

FIG. 1 - Pot2 rep-PCR analysis showing DNA fingerprinting profiles of Pyricularia grisea isolates from rice (Oryza sativa) cultivars Epagri 108 and 109. $\mathrm{M}$ = Size marker Lambda 100 bp, Gibco BRL. Isolates numbers correspond to the numbers indicated in the dendrogram. 


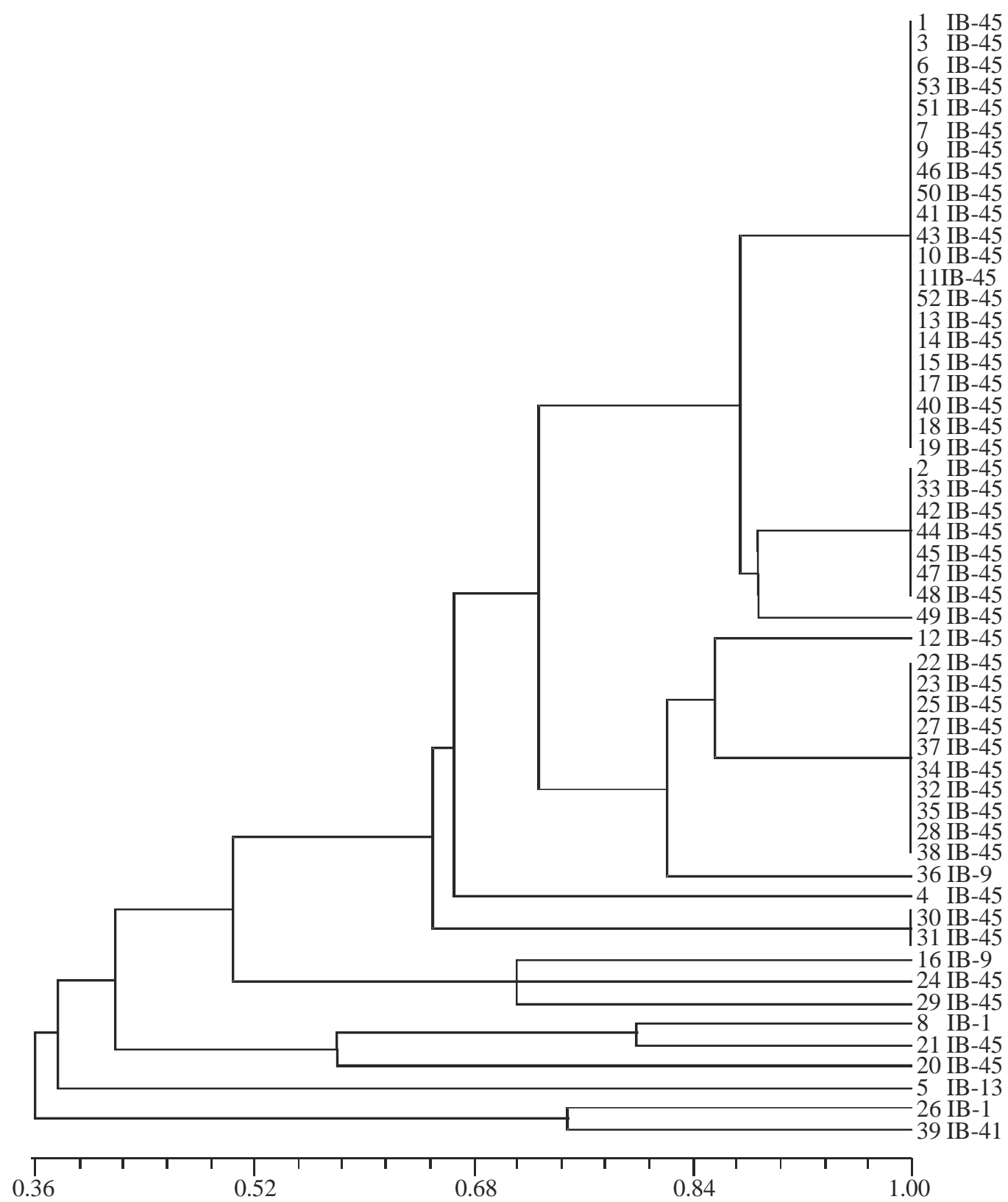

FIG. 2 - Dendrogram of 53 Pyricularia grisea isolates from rice (Oryza sativa) cultivars Epagri 108 and 109, constructed using UPGMA based an Jaccard's similarity coefficients; data from Pot 2 repPCR analysis; scale at the bottom represents coefficients of similarity.

108 and 109 formed a single group (Group I) considering Jaccard coefficient value of $70 \%$. Even though the rest of the isolates did not form into a distinct group they were clustered into Group II. Group II with similarity coefficient values ranging from 0.36 to 1.0 was not well defined and could be considered as six subgroups, each comprised one to three isolates. The pathotypes other than IB-45 such as IB-9, IB-1, IB-13 and IB-41 were included in this group. There seems to be no relation between the pathotypes and rep-PCR based analysis. However, the cluster analysis of the PCR banding pattern of $P$. grisea isolates showed close correspondence between the groupings based on Pot 2 and the phenotypic virulence (Figures 2 and 3). The correlation between Jaccard coefficients of rep-PCR and phenotypic virulence was positive and significant $(r=0.38 ; p=0.01)$. Among the undefined group of isolates, genetic diversity was evident even though it was not exhibited in phenotypic virulence analysis. These results indicate the utility of rep-PCR analysis for identifying genetic differences among isolates which are not evident otherwise.

The similarities in phenotypic virulence among the 53 isolates of $P$. grisea are shown in the dendrogram (Figure 3 ). At $77 \%$ only one group was distinguished, with the exception of one isolate No. 39 pertaining to the pathotype 


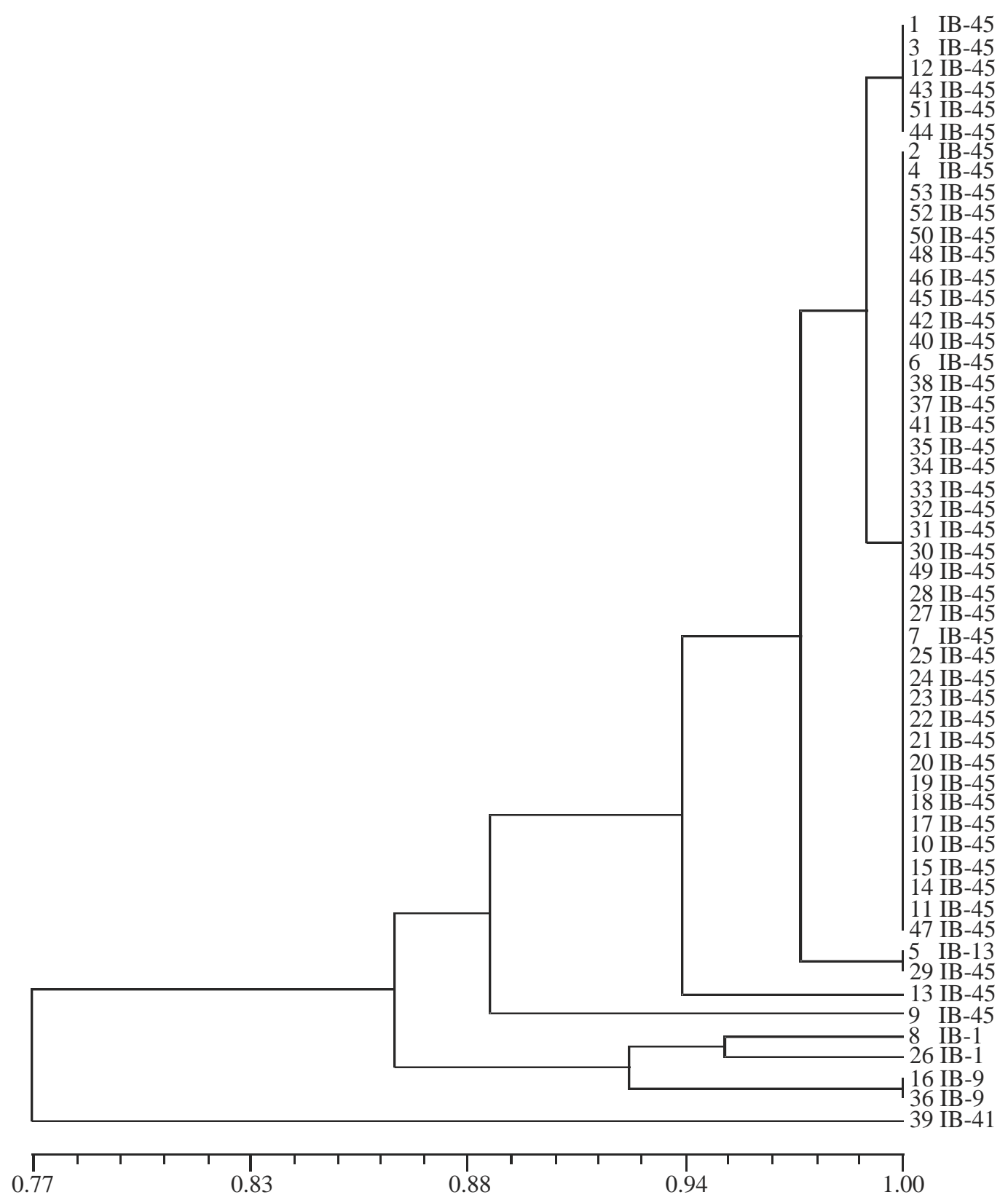

FIG. 3 - Dendrogram of 53 Pyricularia grisea isolates from rice (Oryza sativa) cultivars Epagri 108 and 109, constructed using UPGMA based an Jaccard's similarity coefficients; data from phenotypic virulence analysis; scale at the bottom represents coefficients of similarity.

IB-41. The predominant pathotype IB-45 was represented by 47 of the 53 isolates corresponding to $83 \%$.

The results of pathotype analysis as well as rep-PCR grouping of isolates collected from nine different farms in the municipality of Lagoa da Confusão during 1998-99 growing season are summarized in Table 1. All 53 isolates collected from cultivars Epagri 108 and Epagri 109 showed a similar reaction pattern on the eight standard international differentials with few exceptions. Forty-seven of the 53 isolates pertained to the pathotype IB-45. Four other pathotypes identified among the isolates collected from these cultivars were in low frequency. They included two each of pathotypes
IB-1 and IB-9 and one each of IB-41 and IB-13. These pathotypes were recovered at random in different farms both from Epagri 108 and Epagri 109. It is interesting to observe that the occurrence of these four pathotypes in upland rice cultivars was also reported in earlier studies (Prabhu \& Filippi, 1989). Seven pathotypes were identified among the 24 isolates collected from rice blast screening nursery and experimental plots in Goiânia. Pathotype IB-9 was recovered from eight of the 11 cultivars. The predominant pathotype (IB-45) on Epagri 108 and Epagri 109 in farmers' fields in Tocantins was also recovered from CICA-8 and Oryzica-L5 (Filippi $e t$ al., 1999). These results showed the preexistence of this 
Genetic and phenotypic characterization of isolates of Pyricularia grisea from ...

TABLE 1 -Isolates collected from rice (Oryza sativa) cultivars Epagri 108 and Epagri 109, their origin, international pathotypes and lineages of Pyricularia grisea based on Pot 2 rep-PCR analysis

\begin{tabular}{|c|c|c|c|c|c|}
\hline Number $^{1}$ & ACC. NO. ${ }^{2}$ & Identification $^{3}$ & Origin $^{4}$ & Pathotype $^{5}$ & $\begin{array}{c}\text { Rep-PCR } \\
\text { group }^{6}\end{array}$ \\
\hline 1 & 1634 & EP109L2 ${ }^{1}-99$ & F1 & IB-45 & I \\
\hline 2 & 1636 & EP109L4 ${ }^{1}-99$ & $\mathrm{~F} 1$ & IB-45 & I \\
\hline 3 & 1637 & EP109L5 ${ }^{1}-99$ & F1 & IB-45 & I \\
\hline 4 & 1638 & EP109L $5^{2}-99$ & F1 & IB-45 & II \\
\hline 5 & 1639 & EP109L6 ${ }^{1}-99$ & F1 & IB-13 & II \\
\hline 6 & 1641 & EP109L8 ${ }^{1}-99$ & F1 & IB-45 & I \\
\hline 7 & 1642 & EP109L91-99 & F1 & IB-45 & I \\
\hline 8 & 1644 & EP109L11 1'-99 & F1 & IB-1 & II \\
\hline 9 & 1645 & EP108L1'-99 & $\mathrm{F} 2$ & IB-45 & I \\
\hline 10 & 1647 & EP108L3 ${ }^{1}-99$ & $\mathrm{~F} 2$ & IB-45 & I \\
\hline 11 & 1648 & EP108L $32-99$ & $\mathrm{~F} 2$ & IB-45 & I \\
\hline 12 & 1650 & EP108L4 ${ }^{1}-99$ & $\mathrm{~F} 2$ & IB-45 & I \\
\hline 13 & 1652 & EP108L4 $4^{3}-99$ & $\mathrm{~F} 2$ & IB-45 & I \\
\hline 14 & 1653 & EP108L5 ${ }^{1}-99$ & $\mathrm{~F} 2$ & IB-45 & I \\
\hline 15 & 1657 & EP108L 71'-99 & $\mathrm{F} 1$ & IB-45 & I \\
\hline 16 & 1658 & EP108L1 ${ }^{1}-99$ & F3 & IB-9 & II \\
\hline 17 & 1659 & EP108L2 $2^{1}-99$ & $\mathrm{~F} 3$ & IB-45 & I \\
\hline 18 & 1662 & EP108L5 $5^{1}-99$ & $\mathrm{~F} 3$ & IB-45 & I \\
\hline 19 & 1664 & EP108L1 ${ }^{2}-99$ & F5 & IB-45 & I \\
\hline 20 & 1665 & EP108L $2^{1}-99$ & F5 & IB-45 & II \\
\hline 21 & 1667 & EP108L $2^{3}-99$ & F5 & IB-45 & II \\
\hline 22 & 1669 & EP108L $3^{2}-99$ & F5 & IB-45 & I \\
\hline 23 & 1670 & EP108L $3^{3}-99$ & F5 & IB-45 & I \\
\hline 24 & 1671 & EP108L $3^{4}-99$ & F5 & IB-45 & II \\
\hline 25 & 1672 & EP108L3 $3^{5}-99$ & F5 & IB-45 & I \\
\hline 26 & 1673 & EP108L4²-99 & F5 & IB-1 & II \\
\hline 27 & 1676 & EP108L $1^{1}-99$ & F6 & IB-45 & I \\
\hline 28 & 1680 & EP108L5 ${ }^{1}-99$ & F6 & IB-45 & I \\
\hline 29 & 1682 & EP108L6 ${ }^{1}-99$ & F6 & IB-45 & II \\
\hline 30 & 1683 & EP108L6 $62-99$ & F6 & IB-45 & II \\
\hline 31 & 1684 & EP108L6 6 -99 & F6 & IB-45 & II \\
\hline 32 & 1687 & EP108L8 $8^{3}-99$ & F6 & IB-45 & I \\
\hline 33 & 1688 & EP108L9 $9^{1}-99$ & F6 & IB-45 & I \\
\hline 34 & 1689 & EP109L $1^{1}-99$ & F7 & IB-45 & I \\
\hline 35 & 1690 & EP109L $1^{3}-99$ & F7 & IB-45 & I \\
\hline 36 & 1692 & EP109L2 $2^{1}-99$ & F7 & IB-9 & II \\
\hline 37 & 1693 & $\mathrm{EP} 109 \mathrm{~L} 2^{2}-99$ & F7 & IB-45 & I \\
\hline 38 & 1695 & EP109L $3^{2}-99$ & F7 & IB-45 & I \\
\hline 39 & 1696 & EP109L4 $4^{1}-99$ & F7 & IB-41 & II \\
\hline 40 & 1697 & EP109L4²-99 & F7 & IB-45 & I \\
\hline 41 & 1698 & EP109L4 $4^{3}-99$ & F7 & IB-45 & I \\
\hline 42 & 1699 & EP109L5 ${ }^{1}-99$ & F7 & IB-45 & I \\
\hline 43 & 1700 & EP109L1 ${ }^{1}-99$ & F11 & IB-45 & I \\
\hline 44 & 1701 & EP109L1 ${ }^{2}-99$ & F11 & IB-45 & I \\
\hline 45 & 1703 & EP109L2 ${ }^{1}-99$ & F13 & IB-45 & I \\
\hline 46 & 1704 & EP109L $2^{2}-99$ & F13 & IB-45 & I \\
\hline 47 & 1707 & EP109L $32-99$ & F13 & IB-45 & I \\
\hline 48 & 1708 & EP109L4 ${ }^{1}-99$ & F13 & IB-45 & I \\
\hline 49 & 1711 & EP109L5 $5^{2}-99$ & F13 & IB-45 & I \\
\hline 50 & 1712 & EP109L6 $1-99$ & F13 & IB-45 & I \\
\hline 51 & 1713 & EP109L6 $6^{2}-99$ & F13 & IB-45 & I \\
\hline 52 & 1714 & EP109L7 ${ }^{1}-99$ & F13 & IB-45 & I \\
\hline 53 & 1716 & EP109L1 ${ }^{1}-99$ & F16 & IB-45 & I \\
\hline
\end{tabular}

${ }^{1}$ Serial number; ${ }^{2}$ Accession number of $P$. grisea culture collection of Embrapa Rice \& Beans; ${ }^{3} \mathrm{EP}$ refers to Epagri, L indicates lesion number, superscript refers to conidial number, two last digits indicate the year of collection; ${ }^{4}$ farm number from which the isolates were collected; ${ }^{5}$ Pathotypes were identified using eight international differentials; ${ }^{6} \mathrm{Groups}$ based on clusters analysis of PCR banding patterns.

pathotype, possibly in low frequency, in other cultivars which caused the sudden outbreak of blast when Epagri 108 and Epagri 109 were introduced in the state of Tocantins.

Conidia derived from different lesions L11, L6 and $\mathrm{L}^{2}$ originating from the same cultivar Epagri 109 and farm
(F1) were identified as pathotypes IB-1, IB-13 and IB-45, respectively. They were all clustered in rep-PCR group II. Furthermore, different monoconidial isolates obtained from the same lesion (EP108L3 ${ }^{2}, \mathrm{EP}^{2} 08 \mathrm{~L}^{3}{ }^{3}, \mathrm{EP} 108 \mathrm{~L} 3^{4}, \mathrm{EP} 108 \mathrm{~L} 3^{5}$ ) and the same farm (F5) were encountered both in rep-PCR groups I and II but classified as the same pathotype IB-45. These results suggest that there is no direct relation between the Pot 2 grouping and pathotypes similar to that observed for the relation between lineages and virulence (Zeigler $e t$ al., 1995).

The virulence pattern of the isolates clustered into group II by rep-PCR analysis, on 32 genotypes is shown in Table 2. Four pathotypes (IB-1, IB-9, IB-13, IB-41) recovered at random from cultivars Epagri 108 and Epagri 109 from different farms, as well as seven isolates of pathotype IB-45 pertained to this undefined group. They showed no difference in virulence on NIL's. Also, all 53 P. grisea isolates tested were avirulent (100\%) to the genes Pi-1 (C101 LAC) and Pi-2 (C101 A51) and virulent to Pi-3 (C104PKT), Pi$4^{\mathrm{a}}(\mathrm{C} 101 \mathrm{PKT})$ and $\mathrm{Pi}-4^{\mathrm{b}}(\mathrm{C} 105$ TTP4L). The genes Pi-1 and $\mathrm{Pi}-2$ could be incorporated in susceptible rice cultivars Rio Formoso, Epagri 108 and 109. The reaction of the 13 isolates on nine commercial rice cultivars was similar, except for one isolate (№ 39) identified as pathotype IB-41. Cultivars Aliança and BR-IRGA 409 among the commercial cultivars and Tetep, utilized as resistant check, showed susceptible reaction.

The pathotype IB-45 was highly virulent on Rio Formoso (17719/5738/IR 21015-72-3-3-3-1), which has the same parentage as Epagri 108 (17719/5738/IR 21015-72-33-3-1), whose resistance was overcome one year after its release for cultivation by Embrapa Rice \& Beans. The field population of $P$. grisea was avirulent to some test genotypes (Table 2); therefore, they can be utilized as parents in crosses with commercial cultivars.

MGR586-DNA fingerprinting of 64 Brazilian isolates of $P$. grisea collected from irrigated and upland rice cultivars in experimental plots, showed that all isolates pertain to 18 distinct lineages and 15 pathotypes. These studies further showed that the isolates recovered from CICA 8 and Metica 1 belonged to two distinct lineages, BZ-A and BZ-10, respectively, indicating the high host specificity of the isolates to the cultivars, under field conditions (Filippi et al., 1996; Filippi et al., 1999). The results of the present study suggested some degree of specialization of isolates of $P$. grisea to the cultivar of origin as indicated by greater frequency of pathotype IB-45, although four other pathotypes were also identified. The ability of pathogens to adapt to the cultivar is immense. When a new cultivar with vertical resistance, such as Epagri 108, is introduced, the pathogen too often matches the resistance with the newly accumulated virulence and the cultivar becomes susceptible (Van der Plank, 1982). Furthermore genetic mutation from avirulence to virulence is an appropriate change in the DNA of the pathogen. Thus the rice blast epidemic in the State of Tocantins can possibly be attributed to the occurrence of a new pathotype IB- 45 . 
TABLE 2 - Virulence analysis of Pyricularia grisea isolates that showed different Pot2 rep-PCR banding patterns (group II) on 32 rice (Oryza sativa) genotypes

\begin{tabular}{|c|c|c|c|c|c|c|c|c|c|c|c|c|c|}
\hline \multirow[b]{2}{*}{ Genotype } & \multicolumn{13}{|c|}{ Isolates $^{1}$} \\
\hline & $\begin{array}{c}8^{2} \\
1644^{3}\end{array}$ & $\begin{array}{c}5 \\
1639\end{array}$ & $\begin{array}{c}39 \\
1696\end{array}$ & $\begin{array}{c}26 \\
1673\end{array}$ & $\begin{array}{c}21 \\
1667\end{array}$ & $\begin{array}{c}20 \\
1665\end{array}$ & $\begin{array}{c}29 \\
1682\end{array}$ & $\begin{array}{c}24 \\
1671\end{array}$ & $\begin{array}{c}16 \\
1658\end{array}$ & $\begin{array}{c}31 \\
1684\end{array}$ & $\begin{array}{c}30 \\
1683\end{array}$ & $\begin{array}{c}4 \\
1638\end{array}$ & $\begin{array}{c}36 \\
1692\end{array}$ \\
\hline Epagri 108 & $S^{5}$ & $S$ & $\mathrm{~S}$ & S & $\mathrm{S}$ & S & $\mathrm{S}$ & $\mathrm{S}$ & $\mathrm{S}$ & $S$ & S & $\mathrm{S}$ & $\mathrm{S}$ \\
\hline Epagri 109 & $\mathrm{~S}$ & $\mathrm{~S}$ & $\mathrm{~S}$ & $\mathrm{~S}$ & $\mathrm{~S}$ & $\mathrm{~S}$ & $\mathrm{~S}$ & $\mathrm{~S}$ & $\mathrm{~S}$ & $\mathrm{~S}$ & $\mathrm{~S}$ & $\mathrm{~S}$ & $\mathrm{~S}$ \\
\hline Rio Formoso & $\mathrm{S}$ & $\mathrm{S}$ & $\mathrm{S}$ & $\mathrm{S}$ & $\mathrm{S}$ & $\mathrm{S}$ & $\mathrm{S}$ & $\mathrm{S}$ & $\mathrm{S}$ & $\mathrm{S}$ & $\mathrm{S}$ & $\mathrm{S}$ & $\mathrm{S}$ \\
\hline Metica-1 & $S$ & $S$ & $S$ & $\mathrm{~S}$ & $S$ & $S$ & $S$ & $S$ & $\mathrm{~S}$ & $\mathrm{~S}$ & $\mathrm{~S}$ & $\mathrm{~S}$ & $S$ \\
\hline Cica-8 & $\mathrm{R}$ & $\mathrm{R}$ & $\mathrm{R}$ & $\mathrm{R}$ & $\mathrm{R}$ & $\mathrm{R}$ & $\mathrm{R}$ & $\mathrm{R}$ & $\mathrm{R}$ & $\mathrm{R}$ & $\mathrm{R}$ & $\mathrm{R}$ & $\mathrm{R}$ \\
\hline Cica-9 & $\mathrm{R}$ & $\mathrm{R}$ & $\mathrm{R}$ & $\mathrm{R}$ & $\mathrm{R}$ & $\mathrm{R}$ & $\mathrm{R}$ & $\mathrm{R}$ & $\mathrm{R}$ & $\mathrm{R}$ & $\mathrm{R}$ & $\mathrm{R}$ & $\mathrm{R}$ \\
\hline Aliança & $\mathrm{R}$ & $\mathrm{R}$ & S & $\mathrm{R}$ & $\mathrm{R}$ & $\mathrm{R}$ & $\mathrm{R}$ & $\mathrm{R}$ & $\mathrm{R}$ & $\mathrm{R}$ & $\mathrm{R}$ & $\mathrm{R}$ & $\mathrm{R}$ \\
\hline BR-IRGA 409 & $\mathrm{R}$ & $\mathrm{R}$ & S & $\mathrm{R}$ & $\mathrm{R}$ & $\mathrm{R}$ & $\mathrm{R}$ & $\mathrm{R}$ & $\mathrm{R}$ & $\mathrm{R}$ & $\mathrm{R}$ & $\mathrm{R}$ & $\mathrm{R}$ \\
\hline Javaé & $\mathrm{R}$ & $\mathrm{R}$ & $\mathrm{R}$ & $\mathrm{R}$ & $\mathrm{R}$ & $\mathrm{R}$ & $\mathrm{R}$ & $\mathrm{R}$ & $\mathrm{R}$ & $\mathrm{R}$ & $\mathrm{R}$ & $\mathrm{R}$ & $\mathrm{R}$ \\
\hline IR-8 & $\mathrm{R}$ & $\mathrm{R}$ & $\mathrm{R}$ & $\mathrm{R}$ & $\mathrm{R}$ & $\mathrm{R}$ & $\mathrm{R}$ & $\mathrm{R}$ & $\mathrm{R}$ & $\mathrm{R}$ & $\mathrm{R}$ & $\mathrm{R}$ & $\mathrm{R}$ \\
\hline IR-36 & $S$ & $S$ & S & S & $S$ & S & S & S & S & S & S & S & $S$ \\
\hline IR-50 & S & S & S & S & $S$ & S & S & S & S & S & S & S & $S$ \\
\hline Basmati-370 & $\mathrm{R}$ & $\mathrm{R}$ & S & $\mathrm{R}$ & $\mathrm{R}$ & $\mathrm{R}$ & $\mathrm{R}$ & $\mathrm{R}$ & $\mathrm{R}$ & $\mathrm{R}$ & $\mathrm{R}$ & $\mathrm{R}$ & $\mathrm{R}$ \\
\hline Colombia-1 & $S$ & $S$ & S & S & $S$ & S & S & S & S & S & S & S & $S$ \\
\hline Oryzica-5 & $\mathrm{R}$ & $\mathrm{R}$ & $\mathrm{R}$ & $\mathrm{R}$ & $\mathrm{R}$ & $\mathrm{R}$ & $\mathrm{R}$ & $\mathrm{R}$ & $\mathrm{R}$ & $\mathrm{R}$ & $\mathrm{R}$ & $\mathrm{R}$ & $\mathrm{R}$ \\
\hline Tetep & $\mathrm{R}$ & $\mathrm{R}$ & $\mathrm{S}$ & $\mathrm{R}$ & $\mathrm{R}$ & $\mathrm{R}$ & $\mathrm{R}$ & $\mathrm{R}$ & $\mathrm{R}$ & $\mathrm{R}$ & $\mathrm{R}$ & $\mathrm{R}$ & $\mathrm{R}$ \\
\hline Yashiro mochi & $\mathrm{S}$ & $\mathrm{S}$ & $\mathrm{S}$ & $\mathrm{S}$ & $\mathrm{S}$ & $\mathrm{S}$ & $\mathrm{S}$ & $\mathrm{S}$ & $\mathrm{S}$ & $\mathrm{S}$ & $\mathrm{S}$ & $\mathrm{S}$ & $\mathrm{S}$ \\
\hline Maratelli & S & S & S & S & S & S & S & S & S & S & S & S & S \\
\hline C 101 LAC & $\mathrm{R}$ & $\mathrm{R}$ & $\mathrm{R}$ & $\mathrm{R}$ & $\mathrm{R}$ & $\mathrm{R}$ & $\mathrm{R}$ & $\mathrm{R}$ & $\mathrm{R}$ & $\mathrm{R}$ & $\mathrm{R}$ & $\mathrm{R}$ & $\mathrm{R}$ \\
\hline C 101 A 51 & $\mathrm{R}$ & $\mathrm{R}$ & $\mathrm{R}$ & $\mathrm{R}$ & $\mathrm{R}$ & $\mathrm{R}$ & $\mathrm{R}$ & $\mathrm{R}$ & $\mathrm{R}$ & $\mathrm{R}$ & $\mathrm{R}$ & $\mathrm{R}$ & $\mathrm{R}$ \\
\hline C 104 PKT & S & S & S & S & S & S & S & S & S & S & S & S & $S$ \\
\hline C 101 PKT & S & S & S & S & S & S & S & S & S & S & S & S & S \\
\hline C 105 TTP4L & S & $S$ & S & $S$ & S & $S$ & S & S & S & S & S & S & $S$ \\
\hline CO 39 & $\mathrm{~S}$ & $\mathrm{~S}$ & $\mathrm{~S}$ & $\mathrm{~S}$ & $\mathrm{~S}$ & $\mathrm{~S}$ & $\mathrm{~S}$ & $\mathrm{~S}$ & $\mathrm{~S}$ & $\mathrm{~S}$ & $\mathrm{~S}$ & $\mathrm{~S}$ & $\mathrm{~S}$ \\
\hline Raminad & $\mathrm{R}$ & $\mathrm{R}$ & $\mathrm{R}$ & $\mathrm{R}$ & $\mathrm{R}$ & $\mathrm{R}$ & $\mathrm{R}$ & $\mathrm{R}$ & $\mathrm{R}$ & $\mathrm{R}$ & $\mathrm{R}$ & $\mathrm{R}$ & $\mathrm{R}$ \\
\hline Zenith & S & $S$ & S & $S$ & S & $S$ & S & S & S & S & S & S & $S$ \\
\hline NP 125 & S & S & $\mathrm{R}$ & S & $\mathrm{R}$ & $\mathrm{R}$ & $\mathrm{R}$ & $\mathrm{R}$ & S & $\mathrm{R}$ & $\mathrm{R}$ & $\mathrm{R}$ & S \\
\hline Usen & S & S & S & S & $S$ & S & S & S & S & S & S & S & S \\
\hline Dular & S & $\mathrm{R}$ & $\mathrm{R}$ & S & $\mathrm{R}$ & $\mathrm{R}$ & $\mathrm{R}$ & $\mathrm{R}$ & $\mathrm{R}$ & $\mathrm{R}$ & $\mathrm{R}$ & $\mathrm{R}$ & $\mathrm{R}$ \\
\hline Kanto & S & $\mathrm{R}$ & S & S & $\mathrm{R}$ & $\mathrm{R}$ & $\mathrm{R}$ & $\mathrm{R}$ & S & $\mathrm{R}$ & $\mathrm{R}$ & $\mathrm{R}$ & $S$ \\
\hline Sha tio tsao & S & S & S & S & $S$ & S & S & S & S & S & S & $S$ & S \\
\hline Caloro & $\mathrm{S}$ & $\mathrm{S}$ & $\mathrm{S}$ & $\mathrm{S}$ & $\mathrm{S}$ & $\mathrm{S}$ & $\mathrm{S}$ & $\mathrm{S}$ & $\mathrm{S}$ & $\mathrm{S}$ & $\mathrm{S}$ & $\mathrm{S}$ & $\mathrm{S}$ \\
\hline Pathotype $^{4}$ & IB-1 & IB-13 & IB-41 & IB-1 & IB-45 & IB-45 & IB-45 & IB-45 & IB-9 & IB-45 & IB-45 & IB-45 & IB-9 \\
\hline
\end{tabular}

${ }^{1}$ Isolates retrieved from cultivars EPAGRI 108 and 109 in nine different farms; ${ }^{2}$ The numbers refer to isolates indicated in dendrograms; ${ }^{3}$ Accession number of $P$. grisea culture collection of Embrapa Rice \& Beans; ${ }^{4}$ Pathotypes were identified using eight international differentials; ${ }^{5} \mathrm{~S}=$ susceptible reaction; $\mathrm{R}=$ resistant reaction.

This pathotype, which pre-existed in low frequency, became widely distributed as a result either of strong selection pressure when Epagri 108 and Epagri 109 were introduced, or the greater fitness of the pathotype IB-45.

\section{LITERATURE CITED}

AMARAL, R.E.M., SOUZA, D.M., MALAVOLTA, U.M.A \& ISSA, E. Raças fisiológicas de Pyricularia grisea Cav. no Estado de São Paulo. O Biológico 45:205-208. 1979.

BEDENDO, I.P., RIBEIRO, A.S. \& CARDOSO, C.N. Variabilidade do fungo Pyricularia oryzae, agente causal da brusone no arroz. Summa Phytopathologica 5:106-109. 1979.
BONMAN, J.M., VERGEL de DIOS, T.I., BANDONG, J.M. \& LEE, E.J. Pathogenic variability of monoconidial isolates of Pyricularia oryzae in Korea and in the Philippines. Plant Disease 71:127-130. 1987.

CORREA-VICTORIA, F.J. \& ZEIGLER, R.S. Pathogenic variability in Pyricularia grisea at a rice blast "hot-spot" breeding site in Eastern Colombia. Plant Disease 77:1029-1035. 1993.

FILIPPI, M.C., PRABHU, A.S. \& LEVY, E.M. Differential compatibility of Pyricularia grisea isolates with some Brazilian irrigated rice cultivars. Fitopatologia Brasileira 24:447-450. 1999.

FILIPPI, M.C., PRABHU, A.S. \& LEVY, E.M. Espectro de virulência de isolados e linhagens de Pyricularia grisea em arroz. Fitopatologia Brasileira 21:398. 1996. (Resumo). 
Genetic and phenotypic characterization of isolates of Pyricularia grisea from ...

GEORGE, M.L.C., NELSON, R.J., ZEIGLER, R.S. \& LEUNG, H. Rapid population analysis of Magnaporthe grisea by using rep-PCR and endogenous repetitive DNA sequence. Phytopathology 88:223-228. 1998.

GIATGONG, P. \& FREDERIKSEN, R.A. Pathogenic variability and cytology of monoconidial subcultures of Pyricularia oryzae. Phytopathology 59:1152-1157. 1969.

HAMER, J.E. Molecular probes for rice blast disease. Science 252:632-633. 1991.

KACHROO, P., LEONG, S.A. \& CHATOO, B.B. Pot2, an inverted repeat transposon from the rice blast fungus Magnaporthe grisea. Molecular General Genetics 245:339-348. 1994.

LEUNG, H., BORROMEO, E.S., BERNARDO, M.A. \& NOTTEGHEM, J.L. Genetic analysis of virulence in the blast fungus Magnaporthe grisea. Phytopathology 78:1227-1233. 1988.

LEVY, M., CORREA-VICTORIA, F.J., ZEIGLER, R.S., XU, S. \& HAMER, J. Genetic diversity of the rice blast fungus in a disease nursery in Colombia. Phytopathology 83:1427-1433. 1993.

LEVY, M., ROMÃO, J., MARCHETTI, M.A. \& HAMER, J.E. DNA fingerprinting with a dispersed repeated sequence resolves pathotype diversity in the rice blast fungus. Plant Cell 3:95102. 1991.

OU, S.H. \& AYAD, M.R. Pathogenic races of Pyricularia oryzae originating from single lesions and monoconidial cultures. Phytopathology 58:179-182. 1968.

OU, S.H. Pathogenic variability and host resistance of the rice blast fungus, Pyricularia grisea Cavara. Annual Review of
Phytopathology 18:167-187. 1980.

PRABHU, A.S. \& FILIPPI, M.C. Physiologic races of Pyricularia oryzae virulent on improved upland rice cultivars. Fitopatolologia Brasileira 14:140. 1989. (Resumo).

PRABHU, A.S. \& FILIPPI, M.C. Padrão de virulência dos isolados de Pyricularia grisea provenientes da cultivar Epagri 108, de lavouras de arroz. Fitopatolologia Brasileira 24:319. 1999. (Resumo).

RAEDER, U. \& BRODA, P. Rapid preparation of DNA from filamentous fungi. Letters in Applied Microbiology 1:17-20. 1985.

RIBEIRO, A.S. \& TERRES, A.L.S. Variabilidade do fungo Pyricularia oryzae e sua relação com cultivares resistentes à brusone. Fitopatolologia Brasileira 12:316-321. 1987.

URASHIMA, A.S. \& ISOGAWA, Y. Identification of races of Pyricularia oryzae causing blast disease in variety IAC 4440 in Paraíba Valley-SP. Summa Phytopathologica 16:243-247. 1990.

VAN DER PLANK, J.E. Host-pathogen interaction in plant disease. London. Academic Press. 1982. 207p.

WILLIAMS, J.G.K., KUBELIK, A.R., LIVAK, K.J., RAFALSKI, J.A. \& TINGELYS, V. DNA polymorphism amplified by arbitrary primers are useful as genetic markers. Nucleic Acids Research 18:6531-6535. 1990.

ZEIGLER, R.S., COUC, L.X., SCOTT, R.P., BERNARDO, M.A., CHEN, D.H., VALENT, B. \& NELSON, R.J. The relationship between lineage and virulence in Pyricularia grisea in the Philippines. Phytopathology 85:443-451. 1995. 